\title{
Online Technology and Marketing of Financial Services in Nigeria: An Impact Analysis
}

\author{
Dr. Rachael O. Folorunso, Dr. J. J. Adefila and Mustapha Momoh ${ }^{1}$ \\ Mcpn, Mncs, Amnim \\ ${ }^{1}$ Department of Business Management, University of Maiduguri, PMB 1069, Maiduguri Borno State, Nigeria. \\ ${ }^{1}$ Department of Accountancy, University of Maiduguri, PMB 1069, Maiduguri, Borno State, Nigeria.
}

\begin{abstract}
This study extracts and analyse basic information from Service providers and customers reporting the performance and challenges of online marketing of financial services in Nigeria. Staff and customers of twelve (12) out of the leading financial institutions in Nigeria, with track records of online activities were purposively sampled with the aid of structured questionnaires, to elicit ex post facto facts for use in this study. The resultant data were analysed with the use of descriptive statistics and Pearson Correlation Coefficient using statistical package for social sciences (SPSS), version 16. The study reveals low impact; meaning the country has not realises her full potentials in harnessing online technology for marketing of financial services. It also reveals incidence of challenges associated with implementation and performance of online marketing of financial services in Nigeria which include fluctuation in online services due to poor infrastructure, high rate of online fraudsters, slim awareness on the part of the customers, e-payment bottleneck, among others. Finally, this study expounds a number of management options to stimulate the impacts of online technology in marketing financial services in Nigeria.
\end{abstract}

Keywords: Online Technology, implementation, Marketing, financial services, performance

\section{Introduction}

It is a known fact that online technology has a clear impact on the operational aspect of service organisations in diverse field of human endeavour. That online technology induces change is not contestable, but the progression or trends of the change attracts managerial debate and ongoing research till date, particularly its implication for business and economic developments.

Looking into the manner in which organisations use online technology generally, three phases of change are noted: first the design of information systems to increase the efficiency of operations; second phase, is to adopt the change without disrupting or shutting down the operations of the organisation; and the third phase, is to use the technology to shape the structure and tasks of the organisation itself.

The significance of online technology and the power created for the control over organisational growth and development cannot be over emphasised. The challenges created by the online technology is purely strategic in nature and that institutions pursuing economic development face an urgent need to embrace online technology to cope with globalisation in the face of present economic meltdown. Therefore, it is imperative to improve and stimulate ICT infrastructure to bring internet access to the reach of all citizenry in a developing economy like Nigeria. There is this ancestral proverb which states that 'the only cure for ignorance is awareness'. Of course, awareness on the potentials of online technology will for sure enhance confidence and creates the pivot for achieving development goals.

Online technology is both a competitive weapon to stimulate productivity and development as well as a means of delivering services in businesses. The world is getting used to online activities and people will naturally feel empty and fruitless, where internet services are not easily accessible. Indeed, many would have considered such situation as a declaration of state of emergency, where the fundamental rights of freedom of people are contained.

The central point is that marketing is an area of business in which companies has a choice between ends and means. The use of online technology and these choices can and should be branded and weighed up well ahead of the anticipated change in business environment. This is one element to be pursued by contemporary financial institutions in general and Nigerian financial market in particular. If one accepts the notion that in organisational term, information is a source of unity that provides common ground among decision makers; then, the stage is set for seeing it as a source of influence for organisational functionality. Indeed, information has been increasingly recognised as an economic weapon for the pursuit of business ends. It is apparent from a vast literature search that the fundamental impact of online technology on marketing financial services in Nigerian has not been widely documented, leaving a wide gap in the available literature. To fill this research cavity therefore, this study tries to uncover the performance of online technology in marketing of financial services among the financial institutions in Nigeria. 
Discussed in this paper are objectives of the study, research hypothesis, literature review, research methodology, data presentation and analysis, Results and discussion, conclusions and recommendations.

\author{
Objectives of the study are to: \\ i. assess the impact of online marketing of financial services in Nigeria. \\ ii. identify the challenges of implementation of online marketing of financial services in Nigeria. \\ iii. find appropriate management options to improve online marketing of financial services in Nigeria.
}

The study hypothesised $\left(\mathrm{H}_{0}\right)$ that: there is no significant impact of online marketing of financial services in Nigeria.

\title{
II. Literature Review
}

Taking the criterion of differences in operational marketing, the existence of discrepancies between the financial institutions - competing on services by adapting their offerings to meet customer needs is quite evident. Abideen and Saleem (2011) observe that in the global business environment majority of organisations first determines what their current and potential customer's desire, and then builds the products or services accordingly to maximise profit and to create strategic networks of goals. They further argued that marketing opinion and practice is justified in the trust that customers use a product/service because they have a need, or because a product/service has a perceived benefit.

Indeed, the concern of the contemporary studies in this area has been with the tardiness of the developing countries in adopting online technology for marketing products/services and the consequences on economy development. Dwelling on the opinions of Gronroos (1982), financial institutions should develop new theory of services marketing in line with the traditional model to provide for products/service marketing. Again, Abideen and Saleem (2011) argue that in the theory of market orientation, two concepts are delineated; the 'responsive market orientation'-which addresses the expressed needs of customers and the 'proactive market orientation'- which addresses the hidden needs of customers that is, opportunities for customer value of which the customer is oblivious. In this wise, Narver, Slater and Mac Lachlan (2004) examine empirical relationship between new product success and market orientation and found that proactive market orientation's impact on new-product success is larger than that of responsive market orientation. Similarly, Guo (2002) founds a correlation among customer expectations, perceived service, service quality, market shares, and sales growth. There are perceived challenges such as strategy, structures and systems to developing market orientation which is directly related to leadership style (Harris and Ogbonna, 1998 and Abideen and Saleem, 2011). These studies have it that, a strong relationship between service quality, customer relationship management and market orientation will definitely increase the profitability and performance of businesses.

However, the present study focuses on issue of rather deeper significance, the utilisation of online technology on marketing of financial services and its impact and challenges in Nigeria. Iinnovation can create true competitive advantage in business. Agarwal, Erramilli and Dev (2003) observe that business performance is directly associated with market orientation and innovation. On this note, Ihekweaba and Ihekweaba (2009) add that ICT tools have enhanced banking operations in such a manner that transactions are made from remote locations. They argue further that Automated Teller Machine (ATM) has brought an aspect of financial services to the doorsteps of customers thus reducing the rigours of banking. Indeed, online sales are often faster, cheaper and more convenient than conventional methods of bettering goods and services (Networksolutions, 2009 and PeopleLink, 2009). Indeed, online technology has reduced the global market to a market very much smaller than the village market; where shopping, selection, payment and service delivery are possible at homes, in offices and along the streets (Ihekweaba and Ihekweaba, 2009). The study of NTC (2009) shows that Naushad Trading Company in Kenya had their sales grown from $\$ 10,000$ to over $\$ 2 \mathrm{~m}$ in two years after it went online. Similarly, Uwajie (2003) observes that Microsoft Corporation has earned more profits in 25years than what General Motors earned in 100years. In the words of McNaughton, Osborne and Imrie (2001), understanding the relationship between market orientation and service delivery help firms create customer value and retain customer loyalty.

Indeed, different marketing orientations have emerged in product/service marketing consequent upon advent of online technology for more than two decades now. Indeed, it is paramount to reflect on Piercy (1984) assertions, which specifies three (3) kinds of marketing models that are relevant till date. These include marketing strategy - the formulation of market direction and competitive stance; marketing programmes - the planning and implementation of policies at the customer interface in pricing, communications and delivery; and, marketing information - the processing of data on marketing activities and environment. This framework clears the way for thorough understanding of how the impact of online technology on marketing is being, and will increasingly be felt through its effect on marketing information, which provides feedback to marketing management and strategy formulation. This makes cases for adopting a proactive managerial rather than technical 
stance towards effective utilisation of online technology for service delivery and particularly marketing of financial services in Nigeria.

The diffusion of the technological innovations of online technology appears further than mere forecasting. It has changed the entire orientations that are more fundamental than simply improving the speed and efficiency of business operations. Jones, Busch and Dacinc (2003) argue that technological innovations create opportunity for the market oriented businesses. Similarly, Calantone, Garcia and Droge (2003) identify a broader view of innovation which helps innovation-striving firms to develop conditions and competencies needed to fulfil innovation objectives. In this wise, this study leans on the diffusion of innovation theory purported by Rogger (1995) to achieve the study objectives.

\section{Research Methodology}

The study adopted the survey research using the ex post facto design. Twelve (12) out of the leading financial institutions in Nigeria were purposively sampled. A total of two hundred and forty (240) respondents comprising one hundred and twenty (120) service providers and customers respectively were randomly sampled and used as subjects in the analysis. Two (2) sets of questionnaires were administered; one for financial service providers and the other for customers of the sampled financial institutions in the country. Twenty respondents comprising ten (10) service providers and customers in each selected institutions reported. The questionnaires were developed and validated for use in the study by the researchers to elicit facts on the impacts and challenges face in the implementation of online marketing of financial services in Nigeria. The internal consistency of the instruments was determined though the use of Cronbach's Alpha Coefficients at 0.79 and 0.54 respectively to indicate the construct validity of the questionnaires. The instruments were administered on the 240 reporters within six weeks. All the copies of the administered questionnaires were retrieved and valid for this analysis. The resultant data from this survey exercise were presented and analysed with the use of descriptive statistics and Pearson correlation coefficient.

\section{Data presentation and Analysis}

Financial service providers and their customers were asked to indicate the extent to which the impact of online marketing of financial service has been in Nigeria. Simple percentages frequency on level of impact reported is presented in the Table 1 below in answer to the research questions 1 . The second and third research question was on the major challenges confronting the implementation of online marketing of financial services in Nigeria. The responses from the respondents are summarised in Table 2. The fourth and fifth research question was on the major steps to improve on the current level of online marketing in Nigeria.

Table 1: the impact of online marketing of financial service in Nigeria

\begin{tabular}{|l|l|l|}
\hline Level of Impact & F & Percentage responses \\
\hline Very low & 117 & 48.75 \\
\hline Low & 62 & 25.83 \\
\hline Moderate & 41 & 17.08 \\
\hline High & 15 & 6.25 \\
\hline Very high & 5 & 2.08 \\
\hline Total & 240 & 100 \\
\hline
\end{tabular}

Source: Field survey, 2012

The Table 1 shows that the level of impact of online marketing of financial services is generally low. About $75 \%$ of the reporters attested to this fact. In support of this finding, the study of Eze (2009) reveals that Africa is rated among the least developed countries and must join hand to lunch their own satellites technology to reduce over dependence on Europe and America satellites technology. Indeed, this situation is unacceptable and must be reversed by all means, in order to reposition the country for rapid development.

Table 2: the challenges of online marketing of financial service in Nigeria

\begin{tabular}{|l|l|}
\hline \multicolumn{1}{|c|}{$\begin{array}{c}\text { Critical challenges of online marketing } \\
\text { reported }\end{array}$} & Percentage responses \\
\hline Lack of basic infrastructure & 30.8 \\
\hline Inadequate power supply & 22.7 \\
\hline Lack of requisite knowledge & 13.2 \\
\hline Low level of awareness & 11.7 \\
\hline e-Payment bottleneck & 10.9 \\
\hline High level of Poverty & 4.6 \\
\hline High rate of Illiteracy & 2.5 \\
\hline Poor attitude to change & 2.3 \\
\hline Others & 1.3 \\
\hline Total & 100 \\
\hline
\end{tabular}




\section{Source: Field survey, 2012}

Similarly, financial service providers and their customers were asked to indicate the challenges faced by Nigerian financial institutions in implementing and/or utilising online technology for marketing their services. The Simple percentage frequency of the challenges reported is presented in the Tables 2. Exposition of the facts presented in Table 2 is the most critical challenges hindering the realisation of online marketing of financial service in Nigeria, which include, but not limited to; Lack of basic infrastructure, Inadequate power supply, Lack of requisite knowledge, Low level of awareness and e-payment bottleneck. The results recorded are 30.8\%, 22.7\% and $13.2 \% 11.7 \%$ and $10.9 \%$ respectively. This finding is consistent with Onuka and Oludipe (2004), Owolabi and Olasehinde-Williams (2007) and Eze (2009).

Table 3: steps to improve on the current level of online marketing in Nigeria

\begin{tabular}{|l|l|}
\hline $\begin{array}{l}\text { Summary of major steps to improve online service marketing in } \\
\text { Nigeria }\end{array}$ & Percentage of the respondents \\
\hline Building Nigeria own IT infrastructure & 35.7 \\
\hline Provision of steady power supply & 32.2 \\
\hline Training and sensitisation campaigns & 17.1 \\
\hline Eliminating e-payment bottlenecks & 5.7 \\
\hline Implementation of computer for all policy & 3.8 \\
\hline Enactment of non-repudiation act & 3.8 \\
\hline Others & 1.7 \\
\hline Total & 100.0 \\
\hline
\end{tabular}

\section{Source: Field survey, 2012}

Table 3 presents facts on available management options to improve on the current level of online marketing in Nigeria. The three major options reported by respondents as critical to the successful implementation of online marketing in Nigeria are; building Nigeria own ICT infrastructure (35.7\%), provision of steady power supply $(32.2 \%)$ and training and sensitisation campaigns $(17.1 \%)$ will reversed the current trend of low level of Online marketing in Nigeria. Other options include; eliminating e-payment bottlenecks (5.7\%), implementation of policy on computer for all and enactment of non-repudiation act (3.8\%).

\section{Test of Hypothesis}

The study's null hypothesis $\left(\mathrm{H}_{\mathrm{o}}\right)$ which stated that: "There is no significant impact of online marketing of financial services in Nigeria" was subjected to statistical test with the use of Pearson Correlation Coefficient. The result is presented in table 4, 5 and 6 .

Table 4: Case Processing Summary

\begin{tabular}{|c|c|c|c|c|c|c|}
\hline \multirow{2}{*}{ Observation } & \multicolumn{2}{|c|}{ Valid } & \multicolumn{2}{c|}{ Missing } & \multicolumn{2}{c|}{ Total } \\
\cline { 2 - 7 } & $\mathrm{N}$ & Percent & $\mathrm{N}$ & Percent & $\mathrm{N}$ & Percent \\
\hline $\begin{array}{c}\text { Impact of online marketing of } \\
\text { financial services * Computed result }\end{array}$ & 240 & $100.0 \%$ & 0 & $0.0 \%$ & 240 & $100.0 \%$ \\
\hline
\end{tabular}

Source: Computed from Field Data, 2012

Table 5: Cross tabulation of the Impact of online marketing of financial services in Nigeria

\begin{tabular}{|c|c|c|c|}
\hline \multirow{2}{*}{ Impact of online marketing of financial services } & \multicolumn{2}{|c|}{ Computed result } & \multirow[b]{2}{*}{ Total } \\
\hline & Low impact & High Impact & \\
\hline very low & 117 & 0 & 117 \\
\hline Low & 62 & 0 & 62 \\
\hline & 0 & 41 & 41 \\
\hline \multirow{2}{*}{$\begin{array}{l}\text { High } \\
\text { very high }\end{array}$} & 0 & 15 & 9 \\
\hline & 0 & 5 & 5 \\
\hline Total & 179 & 61 & 240 \\
\hline
\end{tabular}

Source: Computed from Field Data, 2012 
Table 6: Significant Test (Symmetric Measures)

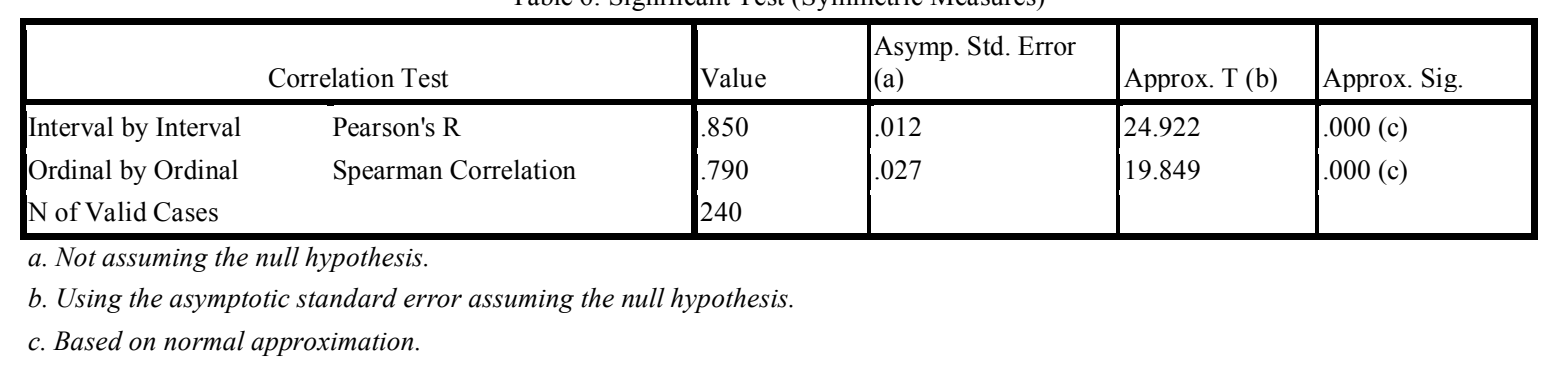

Source: Computed from Field Data, 2012

\section{Results and Decision}

The test shows a Pearson Correlation value of 0.850 at $\mathrm{P}<0.005$. There is positive correlation but low impact of online technology on financial services marketing in Nigeria. The test is statistically significant since $\mathrm{P}<0.05$. Hence, we accept the null Hypothesis $\left(\mathrm{H}_{\mathrm{o}}\right)$ which stated that: "There is no significant impact of online marketing of financial services in Nigeria". This finding is consistent with Eze (2009).

\section{Conclusions and Recommendations}

In view of the above findings, the study concludes as follow:

i. Nigeria is experiencing low impact of online marketing of financial services.

ii. There are number of challenges confronting effective implementation of online marketing in Nigeria which include poor infrastructure, power supply, low level of awareness, e-payment bottleneck, among others.

iii. A number of management options are available to improve on the status quo in Nigeria. This include building Nigeria own ICT infrastructure, provision of steady power supply, training and sensitisation campaigns, eliminating e-payment bottlenecks, implementation of policy on computer for all and enactment of non-repudiation act.

The study recommends the following:

i. Building Nigeria own ICT infrastructure: government and organised private sector most take a giant stride in addressing the problems of poor ICT infrastructure in Nigeria, such as; satellite, VSAT, internet gateways and backbones, ICT centres, localised Internet Service Providers (ISP), modern telecommunication exchanges facilities, Integrated Digital Systems Network (ISDN). This of course, will bring down the cost and increase accessibility to online services.

ii. Provision of steady power supply: Suffice to say that online applications are largely power dependent and the lack of it constitutes impediment to full utilisation of online technology for marketing of financial services.

iii. Training and sensitisation campaigns will reverse the trend of poor attitudes towards online marketing activities in Nigeria. Mavondo, Chimhanzi and Stewart (2005) opine that learning orientation is most important because help determine opportunities and bridges gaps.

iv. Eliminating e-payment bottlenecks: financial institutions should endeavour to provide credit card or master/VISA cards services in local currencies to streamline the complexity in getting dollar based cards and associated fluctuations in the exchange rate.

v. Implementation of policy on computer for all: Computer is a necessity and not luxury. Policies that make every Nigerian own his/her computer set and access to internet is a good one.

vi. Enactment of non-repudiation act: measures should be in place such that parties to online transaction will find it difficult to deny such, thus containing online fraudulent acts.

\section{References}

[1]. Abideen, Z. U. and Saleem, S. (2011). Examining Market Orientation and its Impact on New-Product Success in Pakistan. European Journal of Business and Management (Online) Vol 3, No.4, www.iiste.org.

[2]. Gronroos, C. (1982). 'An Applied Service Marketing Theory’. European Journal of Marketing, Vol. 16, No.7.

[3]. Narver, J. C., Slater, S. F. and Mac Lachlan, D. L. (2004). Responsive and Proactive Market Orientation and New-Product Success. Journal of Product Innovation Management" Volume 21, pp.334-347.

[4]. Guo, C. (2002). Market Orientation and Business Performance: A Frame for Service Organisations. European Journal of Marketing" Volume 36, 9/10.

[5]. Harris, L. C. and Ogbonna, E. (1998). Leadership Style and Market Orientation: An Empirical Study. European Journal of Marketing", Volume 35, No. 5/6

[6]. Agarwal, S. Erramilli, M. K. and Dev, C. S. (2003). Market Orientation and Performance in Service Firms: Role of Innovation. Journal of Service Marketing, Volume 17, No. 1, pp. 68-82.

[7]. Ihekweaba C. and Ihekweaba O.L. (2009). The impact of ICT on Next Generation. Conference proceedings Vol 20, Nigeria Computer Society (NCS), Lagos, Nigeria. 
[8]. Networksolutions (2009). What is Ecommerce? www.ecommerce.networksolutions.com

[9]. People Link (2009). Products on Website. www.peoplelink.org

[10]. NTC (2009). Sales of Local Wood Carving, Pottery and Basket. www.ntclimited.com

[11]. Uwajie C. (2003). Preparing for Knowledge Economy. Conference proceedings vol14, Nigeria Computer Society, Lagos, Nigeria.

[12]. McNaughton, R. B., Osborne, P. and Imrie, B. C. (2001). Market-Oriented Value Creation in Service Firms. European Journal of Marketing, Volume 36, Issue, 9/10.

[13]. Piercy. N., (1984). 'Retailer Marketing — Informational Strategies'. European Journal of Marketing, Vol. 17, No.6.

[14]. Jones, E., Busch, P. and Dacinc, P. (2003). Firm Market Orientation and Salesperson Customer Orientation: Interpersonal and Intrapersonal Influences on Customer Service and Retention in Business-To-Business, Buyer-Seller Relationships, Journal of Business Research, Volume 56, pp. 323-340.

[15]. Calantone, R., Garcia, R. and Droge, C. (2003). The Effects of Environmental Turbulence on New Product Development Strategy Planning. Journal of Product Innovation Management, Volume 20, pp. 90-103.

[16]. Roger, E.M. (1995). Diffusion Innovations (4th ed). Free Press, Pp.206 - 310, New York.

[17]. Onuka, A. O. U. and Oludipe, B.D. (2004). Feedback as poor-performance remediation.

[18]. Education for Today, 4(1), 43-48, Nigeria.

[19]. Owolabi, H.O. and Olasehinde-Williams (2007). An Evaluation of Affective \&

[20]. Psychomotor Behaviours in School Based Assessment; Paper Presented at the 2007 Annual National Conference of the Nigerian Association of Educational Researchers and Evaluators.

[21]. Eze, P. I. (2009). IT and Development in Africa: Empowering future stakeholders. Conference proceedings vol 20, Nigeria Computer Society (NCS), Lagos, Nigeria.

[22]. Mavondo, F. T., Chimhanzi, J. and Stewart, J. (2005). Learning Orientation and Market Orientation Relationship with Innovation, Human Resource Practices and Performance. European Journal of Marketing, Volume 39, No. 11/12, pp. 1235-1263. 